\title{
Impact of Make in India launch on FDI
}

\author{
"Dr. Priyanka Banerji \\ Vice Principal School of Interdisciplinary \& Liberal Studies Suresh Gyan Vihar University \\ Corresponding Author: Dr. Priyanka Banerji
}

\begin{abstract}
Foreign direct investment (FDI) in India has received a thespian enhancement from instigate of the Make in India scheme, as per the most recent Economic Survey. There was a tremendous increase in FDI inflows from October, 2014 to June, 2015, of almost 40\%. This was because of the September 2014 launch of the initiative, which hunted for promoting manufacturing segments and be a magnet for foreign investments. Business entities from various countries like Japan, France, South Korea and China announced that they also intend to endow in India in this make in India scheme. In Make in India scheme, Indian Government has granted 56 defence manufacturing permits to private sector individuals in last one year, this initiative was taken after allowing 49\% FDI in the sector mentioned above in August, 2014, compared with 47 in the last three years. The main goal for the Make in India scheme was to minimize unemployment and increase talent augmentation in various sectors of the economy. According to the Department of Industrial Policy and Promotion, "FDI inflows, under the approval route (which requires prior government permission) increased by 87\% during 2014-15 with an inflow of \$2.22 billion. More than 90\% of FDI was through the automatic route. Also in 2014-15, foreign institutional investment rose by an unparalleled $717 \%$ to $\$ 40.92$ billion". With the continuous increasing trends in GDP, even after demonetization, India has marked its charisma as one of the fastest growing economies of the world. It is ranking among the top 10 striking destinations for various investments. It has become investor friendly in terms of foreign investments. The Government has taken various measures to make a path way to open new sectors so as to attract foreign direct investment. FDI policy modifications are introduced to bring ease of doing business and gear up the velocity of foreign investment in India.
\end{abstract}

This paper aims at explaining the impact of Make in India scheme on FDI.

Keywords: Make in India Scheme, Foreign Direct Investment, GDP and manufacturing units.

\section{Introduction}

Foreign direct investment (FDI) in India has received a thespian enhancement from instigate of the Make in India scheme, as per the most recent Economic Survey. There was a tremendous increase in FDI inflows from October, 2014 to June, 2015, of almost 40\%. This was because of the September 2014 launch of the initiative, which hunted for promoting manufacturing segments and be a magnet for foreign investments. "The concept of Make in India has really succeeded as it added more employment. With this, India has now become a vibrant market for manufacturers. For the products that are made out of the initiative, we have a strong domestic market with increasing demand. I believe that infrastructure sector is where foreign investments can come in a big way," said Dipankar Dasgupta, former professor of economics at the Indian Statistical Institute. Business entities from various countries like Japan, France, South Korea and China announced that they also intend to endow in India in this make in India scheme. In Make in India scheme, Indian Government has granted 56 defence manufacturing permits to private sector individuals in last one year, this initiative was taken after allowing 49\% FDI in the sector mentioned above in August, 2014, compared with 47 in the last three years. The main goal for the Make in India scheme was to minimize unemployment and increase talent augmentation in various sectors of the economy. According to the Department of Industrial Policy and Promotion, "FDI inflows, under the approval route (which requires prior government permission) increased by $87 \%$ during $2014-15$ with an inflow of $\$ 2.22$ billion. More than 90\% of FDI was through the automatic route. Also in 2014-15, foreign institutional investment rose by an unparalleled $717 \%$ to $\$ 40.92$ billion". A state-wise analysis of FDI inflows by the economic survey shows that "Delhi, Haryana, Maharashtra, Karnataka, Tamil Nadu, Gujarat and Andhra Pradesh together attracted more than $70 \%$ of total FDI inflows to India during the last 15 years". "To make the recently launched Make in India initiative a success, the states will have a critical role in facilitating FDI in different sectors," the survey said. "These inflows need perhaps to be examined more closely to determine whether they constitute actual investment or are diversions from other sources to avail of tax benefits under the Double Tax Avoidance Agreement that these countries have with India," the economic survey said. With the continuous increasing trends in GDP, even after demonetization, India has marked its charisma as one of the 
fastest growing economies of the world. It is ranking among the top 10 striking destinations for various investments. It has become investor friendly in terms of foreign investments.

The Government has taken various measures to make a path way to open new sectors so as to attract foreign direct investment. FDI policy modifications are introduced to bring ease of doing business and gear up the velocity of foreign investment in India.

\section{Review Of Literature}

A good number of researches have been conducted on FDI. The study is based on secondary data. Many intellectuals have also focused the significance of FDI in different angles. The reviews of some important scholars are given below.

Singh and Gupta (2013) discussed India's foreign capital policy since 1947. They concluded that the policy framework in India dealing with foreign private investment has changed from cautious welcome policy during 1948-66 to selective and restrictive policy during 1967 to 1979 . In the decade of eighties, it was the policy having partial liberalization with many regulations. Liberal investment climate has been created only since 1991.

(Boopath, 2013) revealed that the Press Council of India has commented on synergic alliance ${ }^{e e}$ or equity participation by way of Foreign Direct Investment. The council opined that Foreign Direct Investment should be allowed to break or halt the growing monopoly of a few media giants in India who offer uneven playground and unhealthy competition to small and medium papers.

(Jampala, 2013)Jampala, Lakshmi and Srinivasa (2013) discussed Foreign Direct Investment Inflows into India in the Post-reforms period. They concluded that "as far as the economic interpretation of the model is concerned; the size of domestic market is positively related to Foreign Direct Investment. The greater the market, the more customers and more opportunities to invest."

(Narayana, 2012)Narayana (2012) explained that one of the major concerns of planners and policy makers in India is attracting more and more Foreign Direct Investment. He analysed the Foreign Direct Investment and its flows into India. He highlighted the basic constraints to investment in general and Foreign Direct Investment in particular.

(5. Chausa \& Tamazian, 2008)Juan Pineiro et. al (2008) in the Paper namely "Does Growth and Quality of Capital markets Drive Foreign capital? - The case of cross-. Border M and As" examined the association between the quantum of FDI in a firm and the quality of capital market growth of that firm. The period of study was from 1987 to 2006. After a comparative study of "both the stock market variables and the financial and regulatory reforms variables, they observed that the coefficients was higher than other variables. They concluded that higher reforms in capital markets may result into higher increase in firm level Foreign Direct Investment". Moreover, the results are found to be enormously forceful when they "replaced stock market variables with squared values of the same, reconfirming the fact that bigger is the escalation, better is the inflow of firm level Foreign Direct Investment".

(Ningombam, 2007) Ningombam, Jayanti (2007) in one of the article entitled " Globalization and Foreign Direct Investment in North East India: A Perspective" has made an attempt to highlight the constraints faced by the north east region (NER) consisting of eight states viz "Assam, Arunachal Pradesh, Manipur Meghalaya , Mizoram , Nagaland, Tripura and Sikkim; focused on the emerging patters and trends in the inflows of foreign investment particularly Foreign Direct Investment in North-East in the wake of economic liberalization initiated in 1991".The findings show that the Foreign Direct Investment has been concentrated in relatively developed states. According to the author, the NER which is at lower stage of development is characterized by extremely attractive scenario yet investment both domestic and foreign is not North-East friendly due to „,crowding out theorye does not work in the region. This article suggested that in the absence of public investment mere opening of the region to the global capital flows will further increase disparities. The reactivation of public investment on the basis of appropriate structure of accountability is, therefore; the need of the hour.

(Parthipan, 2007) Bharathi and Parthipan (2007) in a Paper on "A Comparative Study on Foreign Direct Investment with Particular Reference to India and China" have made an examination of the "Foreign Direct Investments in different economies and their partners into India and China during the period 2001-2005". The crucial assertion of the thesis was to fill the huge gap in attracting non-debt generating Foreign Direct Investment flows, which essentially look into their Foreign Direct Investment - attracting capabilities. The basic focus of the study was to reveal the likely forces for China's triumph in grabbing Foreign Direct Investment inflows. It also explored the "reasons for China"s victory and India's failures to capitalize on the market opportunities. The study explores the pattern of Foreign Direct Investment inflows by the firms into these two countries and their relative picture. The study also analyzed the investment scenario in general to give good reason for the differences and finally to take home flattering and grave explanations for our country. The study mainly focused on areas where it is possible for India to attract larger Foreign Direct Investment inflows provided fitting definite and basic MNC-friendly policies are put in place". "Force has been given to areas like 
real-estate South; export-oriented businesses, and the successful Chinese model of SEZs. The study emphasized the synergy of both the Government and private sector in framing and aiding the Foreign

Direct Investment process". "On the basis of an assessment of the Indian and Chinese data, the thesis reached to the conclusion that India is much behind China in all the areas. This thesis suggests the Indian government to revamp its policies and plans in each of these areas. The other suggestions include advantageous road and rail network, liberal Small Scale Industry rules, lesser product and value prices, low indirect taxes, low import duties on raw materials imports, financial and other boosters to encourage some definite types of investment incentives for new business encouragement, coordination of administration policies".

(Subramanian, 2007) Ramamurthy and Subramanian (2007) in the Paper entitled "Foreign Direct Investment: India Vs. China (A Comparative Analysis- Sector-Wise With a Global Perspective)" stated that India and China are upcoming nations, The growth curve for the one is $\mathrm{U}$-shaped and for other it is $\mathrm{V}$-shaped, but both have a long way to go in attaining their goals. According to authors "presently China is ahead of India in mobilizing inflows through Foreign Direct Investment, but the scenario is fast changing. The facts and figures also showed a growth trend in Foreign Direct Investment inflow in almost all sectors of the growth component". The authors concluded that "the key issues which facilitated, and attracted Foreign Direct Investment inflows into India and probably the issues which make a withdrawal from China, and also the contributory factor of attracting investments in both the countries needs to be debated upon."

(Shilpi, 2007) Nalsar and Prasad (2007) in a paper titled "Foreign Direct Investment and the Legal Profession in India" have investigated into the results of permitting "FDI and foreign collaboration in the legal services sector in India. Many segments of the Indian economy are now moderately open to foreign venture, with few exceptions". "The government has imposed certain restrictions on Foreign Direct Investment in some highly sensitive sectors, e.g. agriculture, retail trading, railways and real estate. According to them some sectors still entail government support. Within the global economy the significance of trade in services currently amounts to well over two trillion US dollars, a sixth of total world trade".

Validation of the Study

After the review of literature, we can say that studies have already been conducted on trends and impacts of FDI in Indian Economy.

The present study has made an endeavor to investigate the impact of make in India launch on FDI.

Objective of the Study

The objective of the study of this research is as follows:

i. To study the efforts of Government of India in correlation with Foreign Direct Investment.

ii. To study and evaluate various aspects pertaining to the performance of FDI in India.

iii. To evaluate the dilemma of flows of FDI after the initiation of make in India launch.

iv. To analyze future prospects of FDI in Indian insurance sector and to critically evaluate the repercussions of increasing the level of FDI from present permissible limit of 49 per cent

\section{Research Methodology}

In order to accomplish these objectives, an attempt has been made in the present study to analyze the growth pattern of FDI in India taking Make in India Launch as the major case study. In this context, the following methodology has been used in the present research work:

(i) Period of Study

For the purpose of analyzing different determinants and parameters of FDI after make in India launch, data on FDI was taken from September 2014 to 2017, as Make in India started in September 2014.

(ii) Sources of Information

For the research work the statistical data was collected from the secondary sources like published and unpublished data collected from different organizations, agencies and government offices. Reputed journals were also used for collecting relevant information.

(iii) Statistical Tools and Techniques

In the context of the objective of our study, different illuminating and methodical statistical techniques were used to investigate the data concerning to our study. For the elucidation of data various statistical tools were used according to the prerequisite and appropriateness of study.

\section{Make in India}

Make in India initiative was launched by Prime Minister of India on 25th September, 2014 to project India as a preferred investment target and a global manufacturing focal point.

The major objective behind the initiative is to refurbish focus on removing unemployment by job creation, skill advancement, nurturing innovation and sky-scraping eminence standards in the industrialized sector. Make in India launch focuses on four key areas to promote industrialization and entrepreneurship. 
- Focus on New Processes \& Initiatives: A number of steps have been taken to improve process of performing business tasks and to promote private enterprises, have been taken under the tutelage of "Make in India".

- Focus on Dynamic Infrastructure: Accessibility of contemporary and dynamic infrastructure is a key ingredient for the growth of industry. Government has proclaimed many programs to reinforce the existing infrastructure.

- Focus on Different Sectors: 25 sectors have been acknowledged in industrialized, services and infrastructure. Further to this, detailed information is being available on interactive web portals. "FDI has been opened up in reserved sectors like defence production, media, and construction and railway infrastructure in big way which allow for greater private sector participation".

- Focus on New Outlook: After this launch, the government approach has shifted from being as regulator to facilitator. "Make in India" launch is bringing an exemplar budge in industrialization and modernization.

All these areas and initiation of the launch has made India as the apex destination all over the world for FDI outshining top economies. This launch has helped the economy to grow in an overall manner, resulting in overall development of the country as a whole.

India has been ranked as the most preferred destination for investment and among the world's fastest growing economies by international agencies. (Ernst and Young, International Monetary Fund, World Economic Situation and Prospects 2015-16, Financial Times, Foreign Policy Magazine, UNCTAD etc.).

The following activities were embarked on through the Make in India initiatives.

1. Hoisting of interactive web portal (India) (http://makeinindia.com):

a) Development of an interactive web portal with detailed information regarding the investment opportunities across identified focus sectors.

b) Highlight central and state government initiatives for ease of doing business.

c) Redirect potential investors to Investor Facilitation Cell, which in turn can provide primary support for all investment related queries.

\section{Market Entry Support Program: Make in India Mittelstand (MIIM)}

MIIM is another milestone in improving the 'Ease of Doing Business' in India. MIIM is designed to attract more German companies to India since it will make the market entry of Mittelstand companies a smooth process. MIIM is geared to address the divergent requirements of manufacturing, technology and service sector companies.

a) Indian embassy in Germany with the support of Government of India has implemented a strategic market entry support programme, first of its kind, to assist German Mittelstand companies in entering the Indian market.

b) MIIM is a highly innovative, integrated platform for market entry services which corresponds to the complex requirements of first time investors. It is a one stop source for companies requiring market entry support services with the additional benefits of special workshops, networking, information exchange etc.

3. Domestic and International Outreach Programs:

a) DIPP in association with industry representative bodies like CII and FICCI participated in following key global events for promotion of "Make in India" and to attract investments to India:

- Hannover Messe in Germany during 13-17th April, 2015

- International Motor Show, 2015 at Frankfurt, Germany during 17th-27th September 2015

- $\quad$ CIFIT at Xiamen, China during 8th- 11th September 2015

- APIDEC at Abu Dhabi during 9th - 12th November, 2015

- $\quad$ DESI, 2015 at London, United Kingdom during 15th - 18th December 2015

- BAUMA CONEXPO AFRICA 2015 at Johannesburg, South Africa during 15-18th December 2015

- MARINTEC China, 2015 at Shanghai, China during 1st-4th December 2015

- $\quad$ Auto Mechanika, Shanghai, China during 2nd - 5th December, 2015

Domestic Events:

- IREE 2015 in Pragati Maidan, New Delhi during 14-16th December, 2015

- $\quad$ EXCON 2015 at Bengaluru, Karnataka during 25th - 29th November 2015

- $\quad$ INDIA PHARMA 2016, BIEC Bengaluru during 7th - 9th January 2016.

Source: Annual Budget 2015-16, Government of India Ministry of Commerce and Industry

Department of Industrial Policy \& Promotion

Actions Completed under the plan:

A. 14 government services delivered via eBiz, a single-window online portal 20 services have been integrated into the portal 
1. Employer Registration (Employee's State Insurance Corporation, 12-Dec-14)

2. Industrial License (Department of Industrial Policy and Promotion, 20-Jan-14)

3. Industrial Entrepreneur Memorandum (Department of Industrial Policy and Promotion, 20-Jan-14)

4. Name Availability (Ministry of Corporate Affairs, 19-Feb-15)

5. Director Identification Number (Ministry of Corporate Affairs, 19-Feb-15)

6. Certificate of Incorporation (Ministry of Corporate Affairs, 19-Feb-15)

7. Commencement of Business 1 (Ministry of Corporate Affairs, 19-Feb-15)

8. Issue of Permanent Account Number (PAN) (Central Board of Direct Taxes, 19-Feb-15)

9. Issue of Tax Deduction Account Number (TAN) (Central Board of Direct Taxes, 19-Feb-15)

10. Reserve Bank of India Advanced Foreign Remittance (AFR)19-Feb- 15

11. Foreign Collaboration-General Permission Route (FC-GPR) (Reserve Bank of India, 19-Feb-15)

12. Employer Registration (Employees' Provident Fund Organization, 19-Feb-15)

13. Issue of Explosive License (Petroleum and Explosives Safety Organization, 19-Feb-15)

14. Importer Exporter Code License (Directorate General of Foreign Trade, 19-Feb-15)

15. Foreign Currency- Transfer of Shares 2 (Reserve Bank of India, 24-Aug-15)

16. Issue of custom duty concession certificate to entrepreneurs under project import scheme (Department of Heavy Industry (DHI), 01-Oct-15)

17. Changes or correction in PAN data (Central Board of Direct Taxes (CBDT), 01-Oct-15)

18. Registration under the Contract Labour Act, 1970 (Ministry of Labour and Employment (MoL\&E), 28Oct-15)

19. Registration under the Building and other construction workers Act, 1996 (Ministry of Labour and Employment (MoL\&E), 28-Oct- 15)

20. Registration under the Inter-State Migrant Workmen Act, 1979 (Ministry of Labour and Employment (MoL\&E), 28-Oct-15)

B. Online portals for Employees State Insurance Corporation (ESIC) and Employees Provident Fund Organization (EPFO) for:

- Real-time registration

- Payments through 56 accredited banks

- Online application process for environmental and forest clearances

C. Department of Commerce, Government of India has launched Indian Trade Portal. Important feature of this portal is to be a single point for relevant information on measures other than tariff called the non tariff measures like standards, technical regulations, conformity assessment procedures, sanitary and Phytosanitary measures which may affect trade adversely.

D. The Companies (Amendment) Act, 2015 has been passed to remove requirements of minimum paid-up capital and common seal for companies. It also simplifies a number of other associated regulatory requirements. It also simplifies a number of other regulatory requirements.

E. An Investor Facilitation Cell has been created in 'Invest India' to guide, assist and handhold investors during the entire life-cycle of the business.

F. The Department of Industrial Policy and Promotion has also set up Japan Plus and Korea Plus. They are special management teams to facilitate and fast track investment proposals from Japan and Korea respectively.

G. Protecting Minority Investors: Greater disclosure of conflicts of interest is now required by board members, increasing the remedies available in case of prejudicial related-party transactions. Additional safeguards have been put for shareholders of privately held companies The Smart Cities Mission is progressing, with Special Purpose Vehicles for 19 cities already setup. Delhi-Mumbai Industrial Corridor is a mega infra-structure project of USD 90 billion with financial and technical aids from Japan, covering an overall length of 1,483 Kms. Source: (India) makeinindia.com

\section{FDI Policy}

The Government has started up with a freethinking policy on FDI, under which FDI, up to $100 \%$, is permitted, under the automatic route, in most sectors/activities. There is a diminutive list of sectors, which are "either prohibited for FDI, or are subject to restrictions in the nature of equity caps, entry route or conditionalities". Further to this, the FDI policy is evaluated on an enduring basis, so as to making it more investor-friendly. Considerable changes have been made in the FDI policy organization in recent times, to make sure that India remains an increasingly striking investment target. In order to liberalize and make FDI a straightforward policy, for providing ease of doing business in the country leading to larger FDI inflows, the Government has brought in FDI related reforms and liberalization of the various sectors / areas of the economy during the year 2015: 
1. Investment made by NRIs, PIOs and OCIs under Schedule 4 of FEMA (Transfer or Issue of Security by Persons Resident outside India) Regulations on non-repatriation basis is now deemed to be domestic investment at par with the investment made by residents.

2. The special dispensation of NRIs has also been extended to companies, trusts and partnership firms, which are incorporated outside India and are owned and controlled by NRIs.

3. $100 \%$ FDI under automatic route for manufacturing of medical devices has been permitted.

4. FDI Policy on Insurance sector reviewed to increase the sectoral cap of foreign investment from $26 \%$ to $49 \%$ with foreign investment up to $26 \%$ to be under automatic route. Similar changes have also been brought in the FDI Policy on Pension Sector.

5. In order to provide simplicity to the FDI policy and bring clarity on application of conditionalities and approval requirements across various sectors, different kinds of foreign investments have been made fungible under one composite cap.

6. FDI up to $100 \%$ through automatic route has been allowed in White Label ATM Operations.

7. Reforms in FDI Policy on Constructions Development sector include:

a) Removal of conditions of area restriction of floor area of 20,000 sq. mtrs in construction development projects and minimum capitalization of US $\$ 5$ million to be brought in within the period of six months of the commencement of business.

b) Exit and repatriation of foreign investment is now permitted after a lock-in-period of three years. Transfer of stake from one non-resident to another non-resident, without repatriation of investment is also neither to be subjected to any lock-in period nor to any government approval.

c) Exit is permitted at any time if project or trunk infrastructure is completed before the lock-in period.

d) $100 \%$ FDI under automatic route is permitted in completed projects for operation and management of townships, malls/ shopping complexes and business centres.

8. Foreign investment up to $49 \%$ in defence sector has been permitted under automatic route along with specified conditions. Further portfolio investment and investment by FVCIs has been allowed up to permitted automatic route level of $49 \%$. The foreign investment in access of $49 \%$ has been allowed on case to case basis with Government approval in case of access to modern and 'state-of-art' technology related manufacturing.

9. Government has decided to introduce full fungibility of foreign investment in Banking-Private sector. Accordingly, FIIs/FPIs/QFIs, following due procedure, can now invest up to sectoral limit of 74\%, provided that there is no change of control and management of the investee company.

10. Government has opened certain plantation activities namely; coffee, rubber, cardamom, palm oil tree and olive oil tree plantations for $100 \%$ foreign investment under automatic route.

11. It has been decided that a manufacturer will be permitted to sell its product through wholesale and/or retail, including through e-commerce under automatic route.

12. Government has reviewed single brand retail trading (SBRT) FDI policy to provide that sourcing of $30 \%$ of the value of goods purchased would be reckoned from the opening of first store. In case of 'state-of-art' and 'cutting-edge technology' sourcing norms can be relaxed subject to Government approval. Further, an entity operating SBRT through brick and mortar stores has been permitted to undertake e-commerce activities as well.

13. Indian brands are equally eligible for FDI to undertake SBRT. In this regard, it has been decided that certain conditions of the FDI policy on the sector namely; products to be sold under the same brand internationally and investment by non-resident entity/ entities as the brand owner or under legally tenable agreement with the brand owner, will not be made applicable in case of FDI in Indian brands.

14. $100 \%$ FDI is now permitted under automatic route in Duty Free Shops located and operated in the Customs bonded areas.

15. FDI policy on wholesale cash \& carry activities has been reviewed to provide that a single entity will be permitted to undertake both the activities of SBRT and wholesale.

16. $100 \%$ FDI is now permitted under the automatic route in Limited Liability Partnerships (LLP) operating in sectors/ activities where 100\% FDI is allowed, through the automatic route and there are no FDI-linked performance conditions. Further, the terms 'ownership and 'control' with reference to LLPs have also been defined.

17. Regional Air Transport Service (RSOP) has been opened for foreign investment up to $49 \%$ under automatic route. Further, foreign equity cap of activities of Non-Scheduled Air Transport Service, Ground Handling Services have been increased from $74 \%$ to $100 \%$ under the automatic route.

18. Foreign investment cap on Satellites-establishment and operation has now been raised from $74 \%$ to $100 \%$ under the government route.

19. Foreign investment cap on Credit Information Companies has now been increased from $74 \%$ to $100 \%$ under the automatic route. 
20. Government has decided that for infusion of foreign investment into an Indian company which does not have any operations and also does not have any downstream investments, Government approval would not be required, for undertaking activities which are under automatic route and without FDI-linked performance conditions.

21. FDI policy on establishment and ownership or control of the Indian company in sectors/activities with caps requiring Government approval has been reviewed to provide that approval of the Government will be required if the company concerned is operating in sectors/ activities which are under Government approval route rather than capped sectors. Further no approval of the Government is required for investment in automatic route sectors by way of swap of shares.

22. Certain conditions of FDI policy on Agriculture and Animal Husbandry, and Mining and mineral separation of titanium bearing minerals and ores, its value addition and integrated activities have been simplified.

23. In order to achieve faster approvals on most of the proposals, the Government has decided to raise threshold limit for approval by FIPB to 5000 crore.

\section{FDI Inflows}

Total FDI into India, since April, 2000 including equity inflows, reinvested earnings and other capital is US\$ 408.68 billion (April, 2000 - December, 2015). During the calendar year 2015, FDI equity inflows of US \$39.33 billion have been received. This represents increase of $37 \%$ over the FDI equity inflows of US \$28.78 billion received during the corresponding period. The FDI equity during the current financial year 2015-16 (up to December, 2015) surged by $40 \%$ to US\$29.44 billion from US \$ 21.04 billion in the year-ago period. During the 19-month tenure of present government, i.e. June, 2014 to December, 2015, FDI equity inflow recorded a growth of $48 \%$ from US \$ 37.24 billion to US\$ 55.06 billion over the preceding period of 19 months (November, 2012 to May, 2014.

\section{Impact on FDI: Recent Policy Measures}

- $\quad 49 \%$ FDI under automatic route permitted in Insurance and Pension sectors

- Foreign investment up to $49 \%$ in defence sector permitted under automatic route. The foreign investment in access of $49 \%$ has been allowed on case to case basis with Government approval in cases resulting in access to modern technology in the country or for other reasons to be recorded

- FDI limit of $100 \%$ (49\% under automatic route, beyond $49 \%$ government route) for defence sector made applicable to Manufacturing of Small Arms and Ammunitions covered under Arms Act 1959

- FDI up to $100 \%$ under automatic route permitted in Teleports, Direct to Home, Cable Networks, Mobile TV, Headed-in- the Sky Broadcasting Service

- $\quad$ FDI up to $100 \%$ under automatic route permitted in Up-linking of Non-'News \& Current Affairs' TV Channels, Down-linking of TV Channels

- In case of single brand retail trading of 'state-of-art' and 'cutting-edge technology' products, sourcing norms can be relaxed up to three years and sourcing regime can be relaxed for another 5 years subject to Government approval

- Foreign equity cap of activities of Non-Scheduled Air Transport Service, Ground Handling Services increased from $74 \%$ to $100 \%$ under the automatic route

- $\quad 100 \%$ FDI under automatic route permitted in Brownfield Airport projects

- FDI limit for Scheduled Air Transport Service/ Domestic Scheduled Passenger Airline and regional Air Transport Service raised to $100 \%$, with FDI up to $49 \%$ permitted under automatic route and FDI beyond $49 \%$ through Government approval

- Foreign airlines would continue to be allowed to invest in capital of Indian companies operating scheduled and nonscheduled air transport services up to the limit of $49 \%$ of their paid up capital

- In order to provide clarity to the e-commerce sector, the Government has issued guidelines for foreign investment in the sector. 100\% FDI under automatic route permitted in the marketplace model of ecommerce

- $100 \%$ FDI under Government route for retail trading, including through e-commerce, has been permitted in respect of food products manufactured and/or produced in India

- $100 \%$ FDI allowed in Asset Reconstruction Companies under the automatic route

- $\quad 74 \%$ FDI under automatic route permitted in Brownfield pharmaceuticals. FDI beyond 74\% will be allowed through government approval route

- FDI limit for Private Security Agencies raised to $74 \%$ (49\% under automatic route, beyond $49 \%$ and up to 74\% under government route)

- For establishment of branch office, liaison office or project office or any other place of business in India if the principal business of the applicant is Defence, Telecom, Private Security or Information and 
Broadcasting, approval of Reserve Bank of India would not be required in cases where FIPB approval or license/permission by the concerned Ministry/Regulator has already been granted

- Requirement of 'controlled conditions' for FDI in Animal Husbandry (including breeding of dogs), Pisciculture, Aquaculture and Apiculture has been waived off.

(Source: www.makeinindia.com)

\section{Foreign investment in Indian manufacturing}

Annual FDI inflows to India in manufacturing (USS billion)

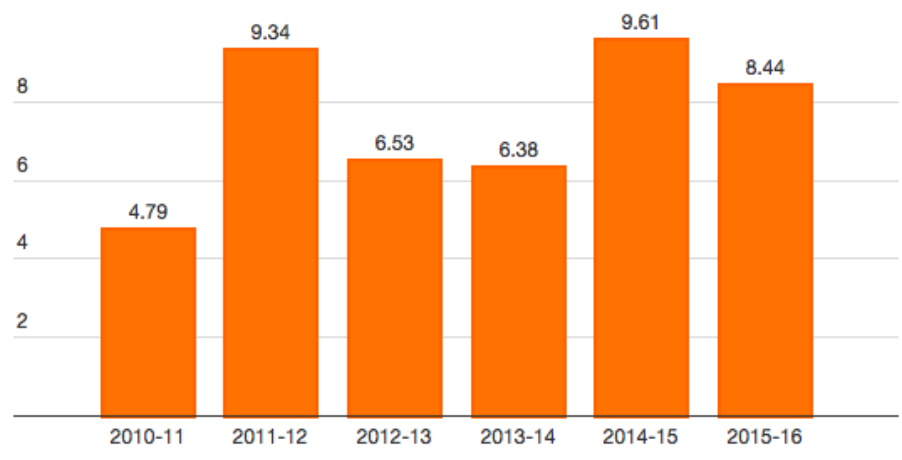

Data for 2015-16 are provisional, but generally do not change.

Note that these numbers cover inflows approved by the RBI and other agencies and exclude share purchases, reinvested earnings and so on. This pattern is consistent with data from the Department of Industrial Policy and Promotion.

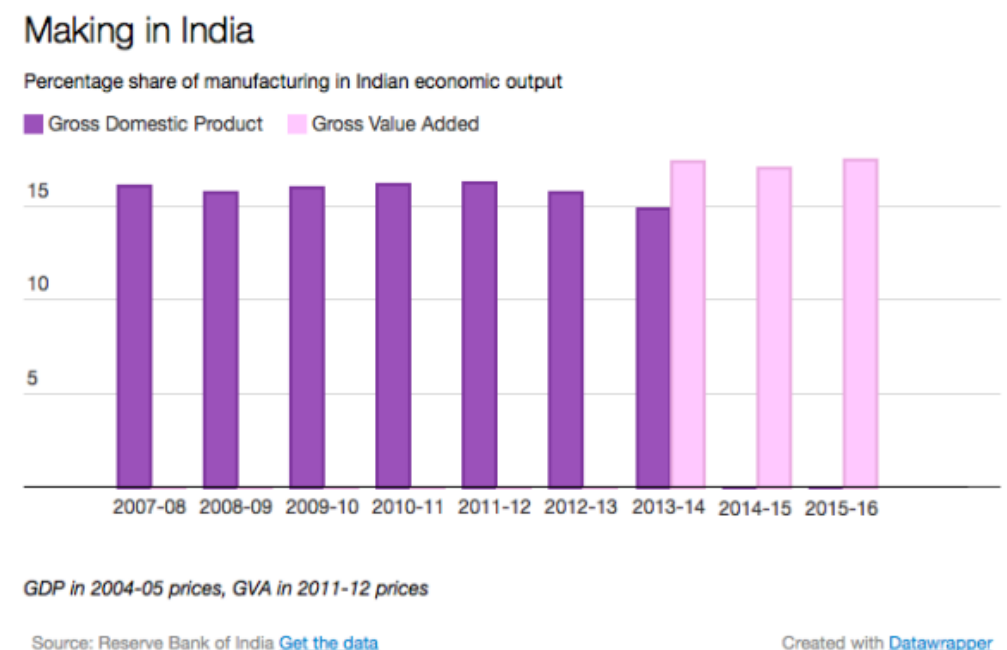

From the above figure, we can see that yet in such a short span no meaningful change has been noted. The share of manufacturing has been flat for the past decade, with a slight downward trend. The rub for this is there is no doubt that building infrastructure, liberalising land and labour laws and improving the ease of doing business is difficult and time consuming and will take time to play out.

\section{The Journey for Make in India: At A Glance}

\section{- September 2014}

The Department of Industrial Policies and Promotion (DIPP) of the Ministry of Commerce and Industry took up a series of measures to improve the Ease of Doing Business to simplify some of the existing rules.

- January 2015

Spice Group announced an investment of US\$ 75.16 million to set up a manufacturing unit for budget smartphones in Uttar Pradesh. 
- $\quad$ February 2015

Chinese technology company Huawei made a huge investment of US\$170 million to set up a new Research and Development (R\&D) campus in Bengaluru. The campus, sprawled across an area of 20 acres, can accommodate 5,000 engineers.

- March 2015

Magneti Marelli, Fiat's component manufacturing arm, started operations for manufacturing of Electronic Fuel Injection (EFI) in a joint venture with leading two-wheeler maker Hero MotoCorp in Manesar.

- May 2015

Hyundai Heavy Industries partnered with Hindustan Shipyard Limited, Visakhapatnam to help build naval ships in India, this collaboration would help India's shipbuilding industry to leap forward tremendously.

Daimler India Commercial Vehicles Pvt. Ltd. (DICV), a 100\% wholly owned subsidiary of Daimler AG, Stuttgart, Germany, announced the inauguration of its new bus manufacturing facility in Oragadam, Tamil Nadu and unveiled its second wave of products - BharatBenz and Mercedes-Benz buses as well as a new range of new BharatBenz high-power engine trucks and BharatBenz heavy-duty tractors.

India moved 13 positions ahead from 65th to 52nd rank in Tourism and Travel Competitive Index as per the World Economic Forum (Davos) Report.

- June 2015

French aircraft manufacturing company LH Aviation signed a Memorandum of Understanding (MoU) with Indian OIS Advanced Technologies (OIS-AT) for manufacturing of tactical drones in India.

India rose to 1st position in the Baseline Profitability Index in 2015. India was ranked at the 6th position in Baseline profitability index in 2014.

- July 2015

In the Global Startup Ecosystem Rankings 2015 Bengaluru moved to \#15 in 2015 from \#19 in 2012 (this was driven by the second highest growth rate in exit volumes and VC investment among the Top 20).

Mercedes Benz India inaugurated its second manufacturing facility in Chakan, which shall double the plant capacity to 20,000 units per annum. The total investment in the manufacturing facility now stands over US\$ 148 million since inception.

- $\quad$ August 2015

Taiwan's Foxconn, the world's largest contract electronics manufacturer and a key supplier to Apple Inc., signed a pact with Maharashtra to invest US\$ 5 billion over five years in a semiconductor manufacturing facility.

The electronics manufacturing sector received a further boost, with Lenovo and Motorola announcing their plans to manufacture smartphones in India in a 40,000 square feet factory in Sriperumbudur near Chennai. The facility currently can create 6 million smartphone units per year.

Xiaomi launched local manufacturing in Visakhapatnam in August 2015 under the Make in India program. The plant exclusively assembles Xiaomi phones and is Xiaomi's second manufacturing unit outside China.

- $\quad$ September 2015

"Make in India Mittelstand initiative" was launched in partnership with Indian embassy in Berlin, Germany for providing Market Entry Support Services like strategic consulting, tax \& legal support, project financing, technology collaboration and facilitation of approvals to German Mittelstand organizations.

Japanese electronics giant Sony got on to the 'Make in India' bandwagon. After nearly a decade, the company is getting back to manufacturing in India, with plans confirmed for two models of its television brand Bravia.

World's largest internet based retailer Amazon opened a warehouse in Pune in September 2015 taking the total count to over 21 with a cumulative storage capacity of over 5 million cubic feet.

- October 2015

India moved up 12 places and reached $130^{\text {th }}$ position in "Ease of Doing Business 2016" report, (World Bank).

India moved up one position to become the world's seventh most valued 'nation brand', with an increase of 32 per cent in its brand value to $\$ 2.1$ billion in 2015. It was the 8th most valued nation in the world in 2014 and ranked 9th in 2013.

- November 2015

India attracted over US\$ 18 billion worth of investments since September 2014 from companies viewing the country as a potential electronics manufacturing powerhouse. Some of the major ones including Samsung, Bosch, Phillips, LG and Flextronics have shown a keen interest in creating their manufacturing bases here.

International Tractors Ltd. (Sonalika) invested US\$ 75 million for setting up its new Hoshiarpur plant in Punjab with the capacity to manufacture 0.2 million tractors per annum. The plant would contain a single production line for all variants and models and an engine assembly line for 500 engines/day. 


\section{- December 2015}

General Electric Transport and Alstom won contracts worth a combined US\$ 5.6 billion to supply India's railways with new locomotives. These foreign companies will help improve the vast but old state-owned network.

Following Japanese PM Shinzo Abe's visit to India, Japan announced setting up a US\$ 12 billion fund for 'Make in India' related projects. This investment will be in the name of 'Japan-India Make in India Special Finance Facility' that will also strengthen the relationship between the countries.

- February 2015

The multi-sectoral Make in India Week (MIIW), a mega event held in Mumbai, was a platform to showcase nation's focus towards design, innovation and sustainability. MIIW was a resounding success which was attended by over 0.9 million visitors from 102 countries and over 8000 B2B/B2G/G2G meetings was conducted over the course of the week.

- $\quad$ March 2016

India achieved its highest ever FDI inflow for a financial year in 2015-16 at US\$ 55.5 billion

Japanese technology giant Hitachi announced its plans to roll out ATMs in India - one of Asia's largest ATM markets - with the investment capital of US\$ 15 million.

- April 2016

US chipmaker Qualcomm plans to establish an innovation lab in Bangalore to provide technical and engineering assistance to the selected companies. It has launched 'Design in India' initiative with the aim to mentor up to 10 Indian hardware companies who have the potential to come up with innovative solutions. India moved up to sixth position amongst the world's leading manufacturers. India has jumped by three positions from ninth position in the previous report. The growth rate of Manufacturing Value Added (MVA) of India was $5.5 \%$ in 2014 and $7.6 \%$ in 2015.

- May 2016

India's Gross Domestic Product (GDP) growth rate for quarter January-March stood at 7.9 per cent as against $7.3 \%$ in October - December, thereby making it the fastest growing major economy in the world.

- June 2016

In a sweeping overhaul of FDI norms, the government radically liberalised key sectors like defence manufacturing, civil aviation, pharmaceutical and food processing, making India as one of the 'most open economy' in the world.

India jumped 13 positions and was placed second in retail potential in the 2016 Global Retail Development Index (GRDI). India was rated 15 in the 2015 Global Retail Development Index.

- July 2016

Actual work on the ground has started on $25 \%$ of investments commitments signed during the Make in India week.

- $\quad$ August 2016

India jumped 15 spots to reach 66th position in Global Innovation Index 2016. India was ranked 81 in 2015. India improved its performance on Logistics Performance Index by 19 positions when compared with its ranking in 2014. India's ranking has jumped from 54 in 2014 to 35 in 2016.

- September 2016

India jumped 16 places to the 39th rank in 2016 from last year's 55th position in the Global Competitiveness Index, highest jump of any country for this year. In 2014 India was in 71st position as per GCI 2014. India has thus jumped 32 positions in two years.

- October 2016

Schneider Electric is preparing to make India its export hub on the back of government's policies such as Make in India, Digital India and Smart City Mission. ${ }^{28}$ Schneider Electric have 28 factories, R\&D centers and further plans to invest around US\$ 110 million in the coming five years and will keep investing in skill development.

The World Bank's annual Doing Business 2017 report placed India in $130^{\text {th }}$ position, recognizing India's achievements in implementing reforms in four of its ten indicators - Trading across Borders, Getting Electricity, Enforcing Contracts and Paying Taxes. Additionally, India's Distance to Frontier score improved on 6 out of the 10 indicators, showing that India is increasingly progressing towards best practice.

Source: (India) www.makeinidia.com

\section{Conclusion}

India has already proved itself as one of the fastest growing economies of the world. It has been ranked among the top 10 attractive destinations for investments from all over the world. It has now become a professional license for investors to approach and endow in the escalation legend of India. Since 1991, the regulatory environment in terms of foreign investment has been consistently eased to make it investor-friendly. 
The measures taken by the Government are directed to open new sectors for foreign direct investment, increase the sectoral limit of existing sectors and simplifying other conditions of the FDI policy. FDI policy reforms are meant to provide ease of doing business and accelerate the pace of foreign investment in the country. Over all scenario of make in India and FDI was a positive summon to prospective investors from all over the world. It represents a wide-ranging refurbish of processes and policies. Earlier, Indian Government was working with a mindset of an issuing authority, but now with the launch of Make in India, it has started working as a Business Partner.

\section{References}

[1] (Boopath, 2013)Boopath, D. (2013) "FOREIGN DIRECT INVESTMENT in Print Media" Foreign Direct Investment and Financial Crisis(Ed.), New Century Publications New Delhi, pp.29-41

[2] (Jampala, 2013) Jampala, Rajesh C., Lakshmi, P.A. and Dokku, Srinivasa Rao (2013) "FOREIGN DIRECT INVESTMENT Inflows into India in the Post-reforms Period" Foreign Direct Investment and Financial Crisis(Ed.), New Century Publications New Delhi, pp.42-58.

[3] Pradeep ,(2013), “Foreign Direct Investment and Industrial Development in India”, Thesis submitted to Maharshi Dayanand University Rohtak for the degree of doctor of philosophy in Department of Commerce

[4] “(Narayana, 2012)” Narayana, N. (2012) Foreign Investment and Indian Economy (Ed), Manglam Publishers \& Distributors, Delhi

[5] (5. Chausa \& Tamazian, 2008) (2008); "Does Growth and Quality of Capital Markets Drive Foreign Capital "; Turkish Economic Association Discussion Paper No. 5, March.

[6] (Ningombam, 2007) Ningombam, Jayanti (2007); "Gobalization and FOREIGN DIRECT INVESTMENT in North East India: A Perspective"; June, Banking Finance, pp.15-18

[7] “(Parthipan, 2007)”S.Vijaykumar Bharathi and P. Parthipan (2007); Delhi Business Review X Vol. 8, No. 1, January-June.

[8] (Subramanian, 2007) Shanta Ramamurthy and R. Subramanian (2007); "Foreign Direct Investments: India vs. China ( A Comparative Analysis-Sector-Wise with a Global Perspective)"; Delhi Business Review X, Vol. 8, No.1, January-June.

[9] (Shilpi, 2007) Shilpi, Nalsar and Priti Prasad (2007); "Foreign Direct Investments and the Legal Profession in India"; Delhi Business Review X Vol. 8, No.1, January-June.

[10] International Yearbook of Industrial Statistics - UNID

[11] (India) http://www.makeinindia.com/home Websites:

[12] http://www.thehindu.com/news/national/modi-reviews-fdi-policy/article8751860.ece

[13] http://www.zed.org.in/

[14] http://www.business-standard.com/article/economy-policy/make-in-india-the-story-so-far-116021200338_1.html

[15] http://articles.economictimes.indiatimes.com/2014-08-16/news/52873678_1_dipp-single-window-clearance-provident-fundorganisation.cms

[16] http://www.huffingtonpost.in/2015/01/28/spice-modi-make-in-india-_n_6559754.htm

[17] http://www.hindustantimes.com/india/make-in-india-korean-major-hyundai-to-build-warships-in-india/storyCekwt529geyURdexWNkROI.html

[18] http://reports.weforum.org/travel-and-tourism-competitiveness-report-2015/index-results-the-travel-tourism-competitiveness-indexranking-2015/

[19] http://chart.fpdatawrapper.com/wzXtv/index.html

[20] http://blog.compass.co/the-2015-global-startup-ecosystem-ranking-is-live/

[21] http://telecom.economictimes.indiatimes.com/news/industry/foxconn-vows-2-billion-push-to-make-in-india-plans-to-set-upmanufacturing-plants-over-next-5-years/48354121

[22] http://articles.economictimes.indiatimes.com/2015-08-18/news/65530665_1_lenovo-india-chennai-plant-motorola-mobility

[23] http://articles.economictimes.indiatimes.com/2015-11-30/news/68661352_1_m-sips-lakh-crore-electronics-sector

[24] http://www.thehindubusinessline.com/economy/logistics/railways-signs-contracts-with-ge-alstom/article7933673.ece

[25] http://articles.economictimes.indiatimes.com/2015-12-13/news/69006246_1_pm-shinzo-abe-india-fund-oda

[26] http://economictimes.indiatimes.com/news/economy/policy/make-in-india-week-gets-rs-15-2-lakh-crore-investmentcommitments/articleshow/51040369.cms

[27] http://articles.economictimes.indiatimes.com/2016-03-17/news/71602413 1 indian-atm-market-hitachi-group-100-crore

[28] http://articles.economictimes.indiatimes.com/2016-04-12/news/72266959_1_digital-india-india-vision-india-initiative

[29] http://www.huffingtonpost.in/2016/05/31/india-gdp-growth-q4-_n_10220172.html

[30] http://indianexpress.com/article/india/india-news-india/the-100-regime-here-are-the-sectors-that-can-now-have-full-fdi-2864533/

[31] https://www.atkearney.com/consumer-products-retail/global-retail-development-index

[32] http://www3.weforum.org/docs/GCR2016-2017/05FullReport/TheGlobalCompetitivenessReport2016-2017_FINAL.pdf

IOSR Journal of Business and Management (IOSR-JBM) is UGC approved Journal with Sl.
No. 4481, Journal no. 46879.

Dr. Priyanka Banerji. "Impact of Make in India launch on FDI." IOSR Journal of Business and Management (IOSR-JBM) 19.7 (2017): 25-35.

I - - - - - - - - - - - - - - - - - - - - - - - - - - - - - - - - 